
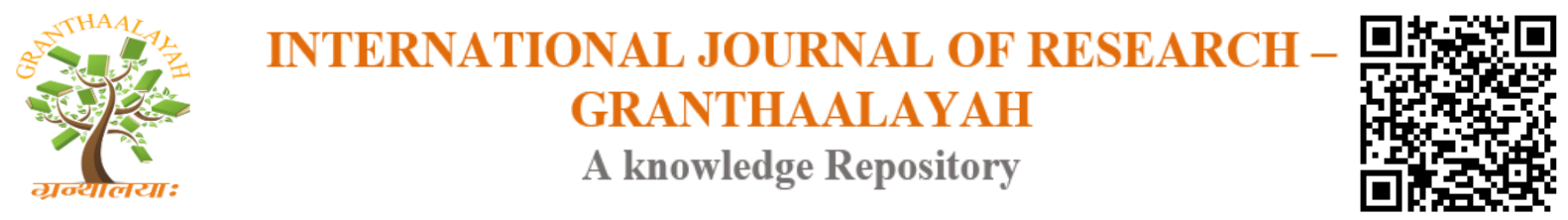

Science

\title{
DETERMINATION OF RADON- 222 CONCENTRATIONS AND EFFECTIVE DOSE BY INGESTION IN GROUND AND SURFACE WATER SOURCES FROM IDAH AND ENVIRONS, NIGERIA
}

\author{
P. M. Gyuk ${ }^{1}$, A. Aruwa ${ }^{* 2}$, M. D. Dogara ${ }^{1}$, I. H. Daniel ${ }^{1}$ \\ ${ }^{1}$ Department of Physics, Kaduna State University, Kaduna, Nigeria \\ ${ }^{* 2}$ Department of Science Laboratory Technology, Federal Polytechnic, Idah, Nigeria
}

\begin{abstract}
Groundwater (well and borehole) and surface water samples from various locations of Idah and environs including have been investigated for their 222Rn concentrations by Liquid Scintillation Counter (Packard Tri-Carb LSA 1000TR) manufactured by Packard Instrument Company. The mean concentration ranges from $4.70 \mathrm{~Bq} / \mathrm{L}$ to $24.0 \mathrm{~Bq} / \mathrm{L}$ for borehole samples, $5.70 \mathrm{~Bq} / \mathrm{L}$ to 13.60 Bq/L and $1.90 \mathrm{~Bq} / \mathrm{L}$ to $4.50 \mathrm{~Bq} / \mathrm{L}$ for well and surface water respectively were found. The average mean concentration of $10.23 \mathrm{~Bq} / \mathrm{L}$ and $12.28 \mathrm{~Bq} / \mathrm{L}$ were found for borehole and well waters respectively which were above the maximum contaminant limit of $11.1 \mathrm{~Bq} / \mathrm{L}$ set by USEPA and $10.0 \mathrm{~Bq} / \mathrm{L}$ by UNSCEAR and WHO. The average mean concentration of $3.05 \mathrm{~Bq} / \mathrm{L}$ was found for surface water making it safe drinking and domestic use. The average total effective dose by ingestion was found to be $0.0412 \mathrm{mSv} / \mathrm{y}$ which is lower than the recommended limit for members of the public of $1.0 \mathrm{mSv} / \mathrm{y}$ and intervention level of $3-10 \mathrm{mSv} / \mathrm{y}$ by ICRP.
\end{abstract}

Keywords: ${ }^{222} \mathrm{Rn}$; Groundwater; Surface Water; Liquid Scintillation Counter; Maximum Contamination Limit; Average Effective Dose.

Cite This Article: P. M. Gyuk, A. Aruwa, M. A. Dogara, and I. H. Daniel (2017). "DETERMINATION OF RADON- 222 CONCENTRATIONS AND EFFECTIVE DOSE BY INGESTION IN GROUND AND SURFACE WATER SOURCES FROM IDAH AND ENVIRONS, NIGERIA." International Journal of Research - Granthaalayah, 5(9), 15-25. https://doi.org/10.29121/granthaalayah.v5.i9.2017.2192.

\section{Introduction}

Water is one of the most abundant substances on earth and is a principal constituent of all living things. It is used in various aspects of daily lives that include power generation, agriculture and domestic activities (ASTM, 1999). It is therefore important for water to be free from chemical, microbiological and radiological contamination (Darko, et al., 2010). Radon is a naturallyoccurring element that contributes to radiological contamination of drinking water and poses a health risk. Since the late 1980s, it has been identified as a health concern. Radon radioactive gas 
is formed when uranium or radium decays. It escapes from the earth's crust through cracks and crevices in the bedrock and either dissolves in ground water or seeps through foundation cracks into the environment/human habitations (Darko, et al., 2010; Farai and Sanni, 1992). Radon is a colourless, odourless radioactive gas that is a daughter element in the decay chain of uranium 238 (Galan, et al., 2004). The alpha radiation emitted by radon and its progeny, polonium, is considered a significant health hazard by the United States Environmental Protection Agency because elevated levels and/or extended durations of exposure can lead to lung cancer. The presence of radon in the earth's crust continuously diffuses through the bedrock, leading to the formation of $222 \mathrm{Rn}$ in ground water. Radon has the highest solubility in water of the noble gas, with a mole fraction value of 0.00125 at $37^{\circ} \mathrm{C}$ and a half-life of 3.8 days, which is 15 times higher than that of helium or neon (Garba, et al., 2010). Because of this property, radon can accumulate in high concentrations in ground water and possess a greater health risk for people who ingest or inhale it.

Radon in water is primarily a problem for water supplies that extract water from drill holes in rocks, which have somewhat higher uranium concentrations than the average bedrock. Some types of rocks that have uranium concentrations greater than $5 \mathrm{ppm}$ of uranium often include granites, syenites, pegmatite, acid volcanic rocks and gneisses. Wells in areas with these rocks may contain ground water with radon concentrations of $50-500 \mathrm{~Bq} / 1$ or considerably higher (IAEA, 2011).

Inadequate potable water is one of the major problems facing most developing nations. Pipe borne water is largely nonoperational where provided; therefore, most of the populace rely heavily on untreated ground water sources as their primary sources of drinking water, and the authorities concerned have not taken serious measures to provide adequate and safe drinking water for the area. Hence, it is important to investigate the radiological content of water from such sources. In Nigeria, particularly in Idah, data on radon concentrations in drinking water sources are lacking, even though most of the inhabitants of the study area, depend solely on ground water and surface water sources for drinking, household activities and agricultural purposes, this water might contain higher-than-normal concentrations of radon. This study aimed to determine the radon concentration and the annual effective dose by ingestion of the ground water sources(borehole and well) and surface water that serve as sources of domestic water for the Idah and its environs. The study was carried out during the dry season between the month of January and February during which the weather was fairly stable. The residents depend solely on ground water sources from wells and boreholes for domestic purposes because of the acute water scarcity during the dry period.

Measurements were carried out using a Liquid Scintillation Counter manufactured by Packard Instrument Company. In liquid scintillation analyzers, energy from emitted radiation is absorbed by a fluorescent material (scintillator or fluorophore) and re-emitted as light photons (Mustapha, et al., 2002; Faria and Sanni, 1992). The light photons are detected by one or more photomultiplier tubes and converted to electrical energy for analysis. The radioactive material is brought into close contact with the scintillator, usually by dissolving both the radioactive material and the scintillator in a suitable solvent; this type of instrument is particularly suitable for the qualitative measurement of radiation with limited penetrating power, such as alpha 
particles, beta particles and soft x-rays. The instrument also has a very short resolving time, so high rates of disintegration can be measured (Thomas, 1987).

\section{Materials and Methods}

The following materials were used in this research as listed by Paul and Stephen (1991) in a publication titled "Determination of Radon in Drinking Water by Liquid Scintillation Counting Method 913.0;

i. Plastic sample collection bottles $(200 \mathrm{ml})$ was used for sample collection

ii. Scintillation cocktail dispenser - adjustable to deliver $10 \mathrm{ml}$.

iii. Liquid scintillation counter (Packard Tri-Carb LSA 1000TR)

iv. Disposable hypodermic syringe $(20 \mathrm{ml}, 10 \mathrm{ml}$ and $2 \mathrm{ml})$ capacity with $38 \mathrm{~mm}$ hypodermic needle.

v. Distilled water

vi. Scintillation vial $-20 \mathrm{ml}$ glass with cap.

vii. Radium solution - required for calibration and check standards

viii. Surgical globe

ix. Indelible ink and masking tape

x. $\quad$ Concentrated nitric acid $\left(\mathrm{HNO}_{3}\right)$

xi. Mineral oil (insta-gel)

\subsection{Sample Selection}

The stratified random sampling (Williams, 1977) was used and in each of the 11 area, six samples were collected with a distance of about $600 \mathrm{~m}$ between one sampling point and the other. A total of 76 sampling points were gotten. Stratified random sampling is a technique which attempts to restrict the possible samples to those which are "less extreme" by ensuring that all parts of the population are represented in the sample in order to increase the efficiency (that is to decrease the error in the estimation).

\subsection{Sample Collection}

Water samples (Dug well, borehole and surface waters) were collected from Ukwaja, Sabongari, Ega, Ede Adejo, Ede Alaba Owoli - Apa, Ofukolo, Ojachapi, Inachalo, Ofiji, and Angwa area in dry cleaned plastic sample bottles. The plastic bottles were first wash cleaned and rinsed with distilled water to avoid radon present in the samples from being contaminated or absorbed.

The water samples from boreholes where collected after the boreholes were operated for at least four minutes. The samples from dug wells were collected with the aid of a bailer, but the stagnant water in the wells was first purged by drawing it out and allowing the well to refill, this was done severally to assure fresh samples were obtained.

The samples were taken to the laboratory immediately after collection without allowing them to stay long (three days maximum) for analysis. This is done so as to achieve maximum accuracy 
and not to allow the composition of the sample to change if it stay long before carrying out the analysis.

\subsection{Sample Preparation}

$10 \mathrm{ml}$ each of the water samples were transferred into a $20 \mathrm{ml}$ glass scintillation vial to which $10 \mathrm{ml}$ of insta-gel scintillation cocktail is added. Having been sealed tightly, the vials were shaken for more than two minutes to extract radon - 222 in water phase into the organic scintillate, and the sample so collected were then counted for 60minutes in a liquid scintillation counter using energy discrimination for alpha particles.

\subsection{Sample Analysis}

The prepared samples were analyzed by using Liquid Scintillation Counter (Tri-Carb LSA 1000TR) model located at the centre for Energy Research and Training (CERT), Ahmadu Bello University, Zaria - Nigeria, after they were allowed to stay for three hour for equilibrium to be attained between radon-222 and its daughter progeny. Measurements were carried out within 24hours after preparation in order to avoid leakage of ${ }^{222} \mathrm{Rn}$ gas. The ${ }^{222} \mathrm{Rn}$ concentration in a sample of water is determined using the formula.

$R_{n}\left(B q L^{-1}\right)=\frac{1000 m L(C S-C B)}{10 m L X 1.0 L(C F X D)}$

Where,

$\mathrm{Rn}$ is Radon level in $\mathrm{BqL}^{-1}$

CS is Sample Count/Second

$\mathrm{CB}$ is Background Count/Second

$\mathrm{CF}$ is Conversion factor

$\mathrm{D}$ is Decay Constant

To calculate the annual effective dose of ${ }^{222} \mathrm{Rn}$ through drinking water, an equation as proposed by the United Nation Scientific Committee on the Effects of Atomic Radiation (Somlai etal., 2002) was used

$\mathrm{E}=\mathrm{K} \times \mathrm{G} \times \mathrm{C} \times \mathrm{T} \times 1000$

2

$\mathrm{E}$ is Annual effective dose ( $\mathrm{mSv} / \mathrm{y})$

$\mathrm{K}$ is Conversion coefficient concentration of ${ }^{222} \mathrm{Rn}(\mathrm{Sv} / \mathrm{Bq})=1.8 \times 10^{-9} \mathrm{~Sv} / \mathrm{Bq}$ for adults

$\mathrm{G}$ is Daily Consumed Water $(\mathrm{L} / \mathrm{d})=2.723 \mathrm{~L} / \mathrm{d}$

$\mathrm{C}$ is Concentration of ${ }^{222} \mathrm{Rn}\left(\mathrm{BqL}^{-1}\right)$

$\mathrm{T}$ is time span of water consumption (365 days)

1000 is Conversion coefficient of $\mathrm{Sv}$ to $\mathrm{mSv}$ 


\section{Results and Discussions}

Table 1: ${ }^{222}$ Rn Concentration and annual effective dose in samples water from Idah

\begin{tabular}{|c|c|c|c|c|c|}
\hline $\mathbf{S} / \mathbf{N}$ & Sample ID & Latitude $\left({ }^{0}\right) \mathrm{N}$ & Longitude $\left(^{0}\right) \mathbf{E}$ & $\operatorname{Rn}(B q / L)$ & $\begin{array}{l}\text { Annual Effective } \\
\text { Dose by Ingestion } \\
(\mathrm{mSv} / \mathrm{y})\end{array}$ \\
\hline 1. & EAW1 & 7.10 & 6.74 & $8.99 \pm 0.85$ & 0.0328 \\
\hline 2 & EAW2 & 7.11 & 6.69 & $10.16 \pm 0.85$ & 0.0371 \\
\hline 3 & EAW3 & 7.13 & 6.72 & $9.99 \pm 0.85$ & 0.0365 \\
\hline 4 & EAW4 & 7.12 & 6.74 & $13.71 \pm 0.85$ & 0.0500 \\
\hline 5 & EAW5 & 7.11 & 6.73 & $14.87 \pm 0.85$ & 0.0543 \\
\hline 6 & EAW6 & 7.12 & 6.73 & $9.33 \pm 0.85$ & 0.0341 \\
\hline 7 & EAW7 & 7.11 & 6.67 & $13.42 \pm 0.85$ & 0.0490 \\
\hline 8 & EAW8 & 7.10 & 6.72 & $14.03 \pm 0.85$ & 0.0512 \\
\hline 9 & EAB1 & 7.09 & 6.68 & $4.56 \pm 0.01$ & 0.0166 \\
\hline 10 & EAS & 7.11 & 6.72 & $4.50 \pm 0.03$ & 0.0164 \\
\hline 11 & APB1 & 7.12 & 6.74 & $3.50 \pm 1.61$ & 0.0128 \\
\hline 12 & APB2 & 7.11 & 6.71 & $2.97 \pm 1.61$ & 0.0108 \\
\hline 13 & APB3 & 7.11 & 6.73 & $7.40 \pm 1.61$ & 0.0270 \\
\hline 14 & APB4 & 7.13 & 6.73 & $9.94 \pm 1.61$ & 0.0363 \\
\hline 15 & UKB1 & 7.11 & 6.73 & $3.15 \pm 2.34$ & 0.0115 \\
\hline 16 & UKB2 & 7.12 & 6.74 & $14.34 \pm 2.34$ & 0.0523 \\
\hline 17 & UKB3 & 7.12 & 6.72 & $9.93 \pm 2.34$ & 0.0364 \\
\hline 18 & UKB4 & 7.11 & 6.74 & $7.56 \pm 2.34$ & 0.0276 \\
\hline 19 & $\mathrm{CB} 1$ & 7.10 & 6.73 & $14.05 \pm 1.29$ & 0.0513 \\
\hline 20 & CB2 & 7.11 & 6.74 & $13.11 \pm 1.29$ & 0.0479 \\
\hline 21 & CB3 & 7.11 & 6.75 & $9.81 \pm 1.29$ & 0.0358 \\
\hline 22 & SB1 & 7.21 & 6.72 & $10.48 \pm 1.67$ & 0.0383 \\
\hline 23 & SB2 & 7.30 & 6.73 & $14.71 \pm 1.67$ & 0.0537 \\
\hline 24 & SB3 & 7.21 & 6.70 & $11.95 \pm 1.67$ & 0.0436 \\
\hline 25 & SB4 & 7.41 & 6.73 & $8.86 \pm 1.67$ & 0.0323 \\
\hline 26 & SB5 & 7.32 & 6.72 & $9.10 \pm 1.67$ & 0.0332 \\
\hline 27 & SB6 & 7.32 & 6.69 & $19.74 \pm 1.67$ & 0.0721 \\
\hline 28 & OFB1 & 7.11 & 6.74 & $12.90 \pm 1.27$ & 0.0106 \\
\hline 29 & OFB2 & 7.12 & 6.73 & $12.82 \pm 1.27$ & 0.0103 \\
\hline 30 & OFB3 & 7.11 & 6.72 & $9.15 \pm 1.27$ & 0.0334 \\
\hline 31 & OFB4 & 7.11 & 6.73 & $7.94 \pm 1.27$ & 0.0290 \\
\hline 32 & IS 1 & 7.12 & 6.74 & $2.90 \pm 0.10$ & 0.0106 \\
\hline 33 & IS2 & 7.14 & 6.72 & $3.25 \pm 0.10$ & 0.0119 \\
\hline 34 & IS3 & 7.13 & 6.73 & $2.70 \pm 0.10$ & 0.0986 \\
\hline 35 & IS4 & 7.14 & 6.74 & $2.78 \pm 0.10$ & 0.0101 \\
\hline 36 & IS5 & 7.13 & 6.74 & $2.71 \pm 0.10$ & 0.0989 \\
\hline 37 & IB1 & 7.11 & 6.75 & $14.57 \pm 1.14$ & 0.0532 \\
\hline 38 & IB2 & 7.14 & 6.72 & $12.16 \pm 1.14$ & 0.0444 \\
\hline 39 & IB3 & 7.14 & 6.75 & $10.63 \pm 1.14$ & 0.0388 \\
\hline 40 & OKB1 & 7.15 & 6.74 & $12.87 \pm 1.83$ & 0.0470 \\
\hline
\end{tabular}




\begin{tabular}{|c|c|c|c|c|c|}
\hline & & & & & 10.5281/zenodo.999191 \\
\hline 41 & OKB2 & 7.15 & 6.72 & $12.66 \pm 1.83$ & 0.0462 \\
\hline 42 & OKB3 & 7.17 & 6.70 & $18.24 \pm 1.83$ & 0.0666 \\
\hline 43 & OKW1 & 7.14 & 6.70 & $12.93 \pm 0.30$ & 0.0472 \\
\hline 44 & OKW2 & 7.16 & 6.74 & $14.09 \pm 0.30$ & 0.0514 \\
\hline 45 & OKW3 & 7.18 & 6.75 & $13.21 \pm 0.30$ & 0.0482 \\
\hline 46 & OKW4 & 7.16 & 6.72 & $14.12 \pm 0.30$ & 0.0515 \\
\hline 47 & OKS & 7.16 & 6.74 & $2.64 \pm 0.03$ & 0.0964 \\
\hline 48 & EGW1 & 7.13 & 6.73 & $3.01 \pm 2.00$ & 0.0110 \\
\hline 49 & EGW2 & 7.14 & 6.74 & $5.70 \pm 2.00$ & 0.0208 \\
\hline 50 & EGW3 & 7.18 & 6.72 & $7.93 \pm 2.00$ & 0.0289 \\
\hline 51 & EGW4 & 7.12 & 6.73 & $6.00 \pm 2.00$ & 0.0219 \\
\hline 52 & EGB1 & 7.12 & 6.72 & $17.94 \pm 1.39$ & 0.0655 \\
\hline 53 & EGB2 & 7.13 & 6.74 & $16.26 \pm 1.39$ & 0.0593 \\
\hline 54 & EGB3 & 7.13 & 6.75 & $13.21 \pm 1.39$ & 0.0482 \\
\hline 55 & EGS1 & 7.13 & 6.72 & $2.77 \pm 0.06$ & 0.0101 \\
\hline 56 & EGS2 & 7.13 & 6.71 & $2.97 \pm 0.06$ & 0.0108 \\
\hline 57 & EGS3 & 7.10 & 6.74 & $2.92 \pm 0.06$ & 0.0107 \\
\hline 58 & EGS4 & 7.14 & 6.99 & $2.62 \pm 0.06$ & 0.0956 \\
\hline 59 & EGS5 & 7.12 & 6.70 & $2.75 \pm 0.06$ & 0.0100 \\
\hline 60 & ANB1 & 7.21 & 6.41 & $15.46 \pm 1.42$ & 0.0564 \\
\hline 61 & ANB2 & 7.24 & 6.43 & $14.89 \pm 1.42$ & 0.0543 \\
\hline 62 & ANB3 & 7.25 & 6.43 & $21.21 \pm 1.42$ & 0.0774 \\
\hline 63 & ANB4 & 7.22 & 6.42 & $13.80 \pm 1.42$ & 0.0504 \\
\hline 64 & ANB5 & 7.23 & 6.33 & $14.10 \pm 1.42$ & 0.0515 \\
\hline 65 & ANB6 & 7.26 & 6.39 & $10.60 \pm 1.42$ & 0.0387 \\
\hline 66 & ANS1 & 7.31 & 6.37 & $1.90 \pm 0.04$ & 0.0694 \\
\hline 67 & ANS2 & 7.28 & 6.39 & $1.88 \pm 0.04$ & 0.0686 \\
\hline 68 & ANS3 & 7.28 & 6.37 & $2.01 \pm 0.04$ & 0.0734 \\
\hline 69 & EBW1 & 7.31 & 6.41 & $7.48 \pm 0.81$ & 0.0273 \\
\hline 70 & EBW2 & 7.33 & 6.43 & $10.24 \pm 0.81$ & 0.0374 \\
\hline 71 & EBW3 & 7.29 & 6.41 & $12.97 \pm 0.81$ & 0.0473 \\
\hline 72 & EBW4 & 7.31 & 6.43 & $10.67 \pm 0.81$ & 0.0389 \\
\hline 73 & EBW5 & 7.32 & 6.40 & $8.01 \pm 0.81$ & 0.0292 \\
\hline 74 & EBW6 & 7.30 & 6.42 & $9.81 \pm 0.81$ & 0.0358 \\
\hline 75 & EBB1 & 7.41 & 6.43 & $12.16 \pm 1.55$ & 0.0444 \\
\hline 76 & EBB1 & 7.38 & 6.42 & $9.07 \pm 1.55$ & 0.0331 \\
\hline & Average & & & & 0.0412 \\
\hline
\end{tabular}

Table 2: Mean radon concentration for borehole water samples

\begin{tabular}{ll}
\hline Sample ID & Mean radon concentration \\
\hline EAB & 4.7 \\
APB & 6.0 \\
UKB & 8.7 \\
CB & 12.3 \\
SB & 24.2 \\
OFB & 10.7
\end{tabular}


IB

$\mathrm{OKB}$

EGB

ANB

EBB
12.5

14.6

15.8

15.0

10.6

Table 3: Mean radon concentration for well water samples

\begin{tabular}{ll}
\hline Sample ID & Mean radon concentration \\
\hline EAW & 11.8 \\
APW & 0.0 \\
UKW & 0.0 \\
CW & 0.0 \\
SW & 0.0 \\
OFW & 0.0 \\
IW & 0.0 \\
OKW & 13.6 \\
EGW & 5.7 \\
ANW & 0.0 \\
EBW & 9.9 \\
\hline Average mean & $\mathbf{1 0 . 2 3}$ \\
\hline
\end{tabular}

Table 4: Mean radon concentration for surface water samples

\begin{tabular}{ll}
\hline Sample ID & Mean radon concentration \\
\hline EAS & 4.5 \\
APS & 0.0 \\
UKS & 0.0 \\
CS & 0.0 \\
SS & 0.0 \\
OFS & 0.0 \\
IS & 3.0 \\
OKS & 0.0 \\
EGS & 2.8 \\
ANS & 1.9 \\
EBS & 0.0 \\
\hline Average mean & $\mathbf{3 . 0 5}$ \\
\hline
\end{tabular}




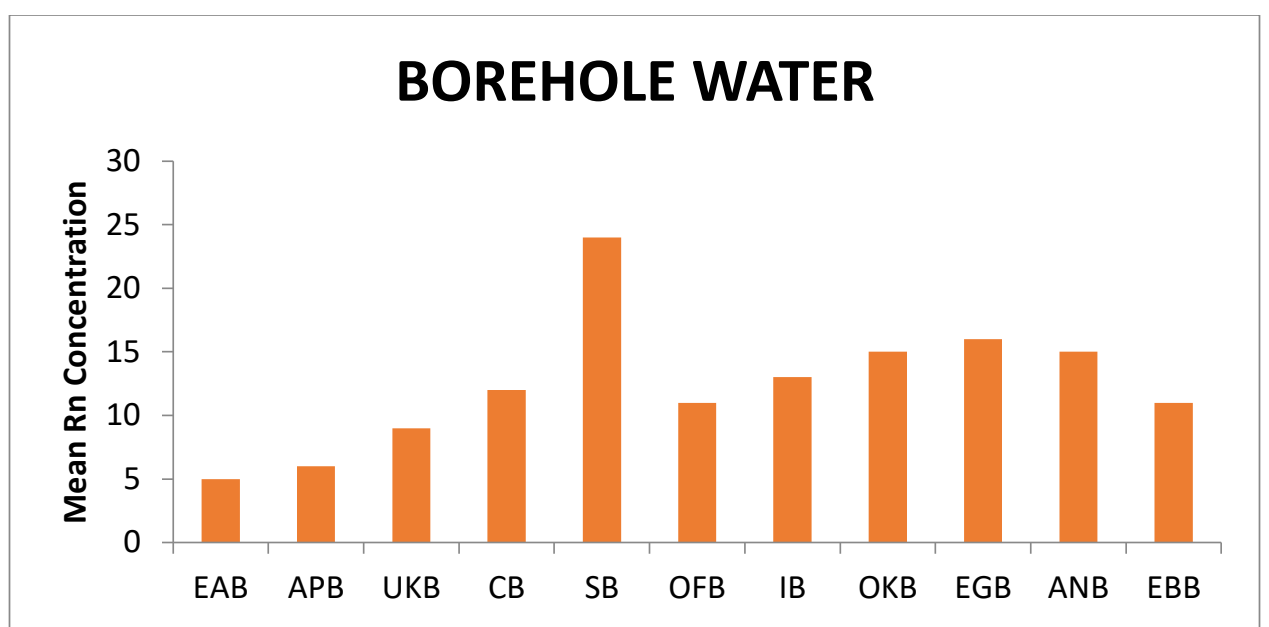

Figure 1: A Plot of Mean ${ }^{222} \mathrm{Rn}$ Concentration obtained from Borehole Water Sources

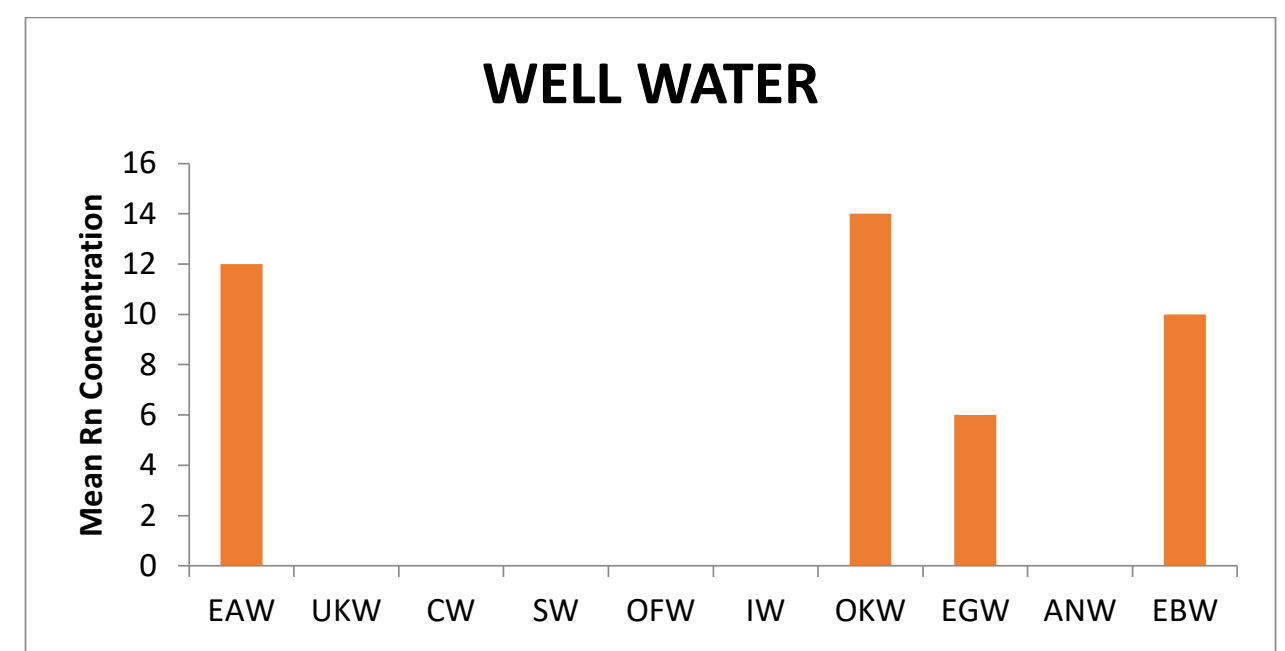

Figure 2: A Plot of Mean ${ }^{222}$ Rn Concentration obtained from Well Water Source

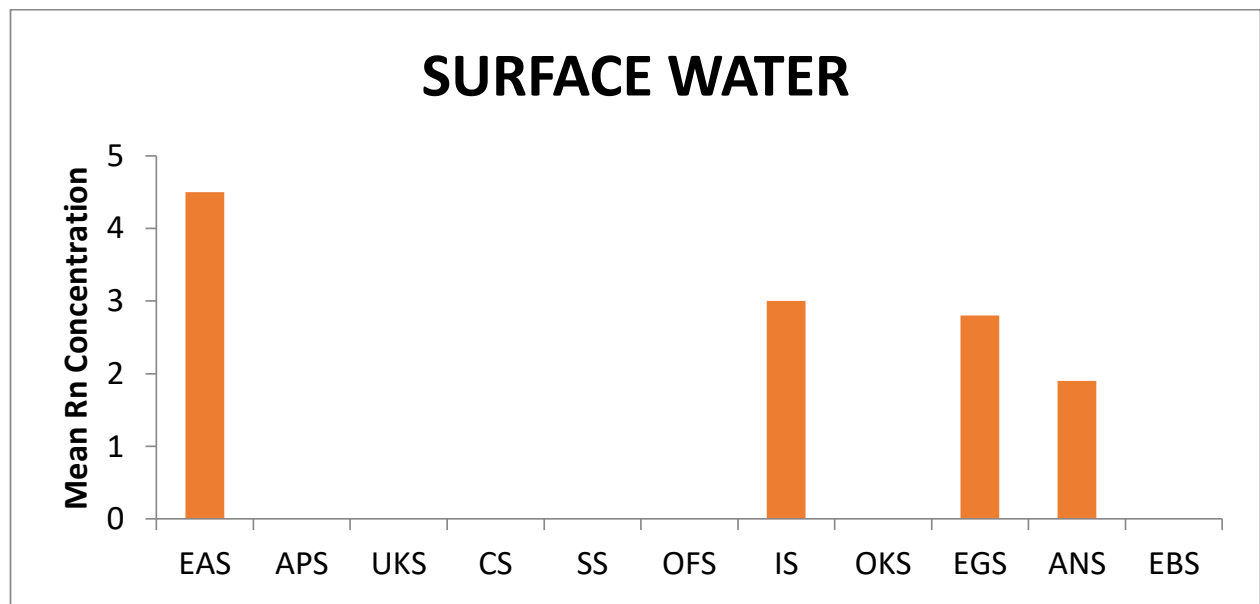

Figure 3: A Plot of Mean ${ }^{222} \mathrm{Rn}$ Concentration obtained from Surface Water Source

In this study, a total of seventy six (76) samples from different water sources where collected. Thirty nine from boreholes, and twenty two from hand dug wells, and fifteen from surface 
sources were collected from the study areas and analyzed by Liquid Scintillation Counting Technique respectively. Figures 1 to 3 showed the frequency distribution pattern for all the boreholes, wells and surface water samples from eleven (11) sampling areas namely, Ate-Idah, Inachalo, Ede-Adejo, Ede-Alaba, Ukwaja, Ojachapi, Sabon gari, Offiji, Inachalo, Ofukolo, Ega and Angwa area with an average mean concentration of $12.28 \mathrm{~Bq} / \mathrm{L}$ for the boreholes, 10.23 $\mathrm{Bq} / \mathrm{L}$ for the wells, and $3.05 \mathrm{~Bq} / \mathrm{L}$ for the surface water sources from all the sampling areas found and were recorded. These results show that the average mean radon concentration for boreholes and wells were greater than the maximum contamination limit (MCL) of $11.1 \mathrm{~Bq} / \mathrm{L}$ set by USEPA (1991) and the world average value of $10.0 \mathrm{~Bq} / \mathrm{L}$ set by the World Health Organization, WHO (1993; UNSCEAR, 1993) and adopted by the Standard Organization of Nigeria (SON, 2003). The mean radon concentrations obtained from surface water samples from this area are relatively below the set mean concentration of $10.0 \mathrm{~Bq} / \mathrm{L}$ by $(\mathrm{WHO}, 1993$; UNSCEAR, 1993) and the maximum permissible value of $11.1 \mathrm{~Bq} / \mathrm{L}$ by USEPA, 1999 respectively. This may be attributed to the rapid escape of dissolved ${ }^{222} \mathrm{Rn}$ from water due to frequent agitation especially during rainy season (Slevasekarapandian et al., 2001). From the forgoing, it can be stated that high radon concentration in groundwater is highly dependent on the type of geologic rock aquifers (Cho et al., 2004). Result from this study showed that the mean ${ }^{222} \mathrm{Rn}$ concentration in both wells and borehole were slightly higher than the maximum concentration limit of $11.1 \mathrm{~Bq} / \mathrm{L}$ and world average value of $10 \mathrm{~Bq} / \mathrm{L}$ for drinking water (Mustapha et al., 2002) and this may be attributed to the fact that radon readily dissolves in water under pressure which lead to the radon accumulation in groundwater (Cho et al., 2004). High concentration of ${ }^{222} \mathrm{Rn}$ has been of great concern about its health effects. Therefore, either drinking groundwater or bathing can give rise to exposure of humans to its radiation and may result in cancer and even death in extreme saturation (USEPA, 1999). Cothern (1990) showed that approximately $1-7 \%$ of lung cancer fatalities in the USA are due to indoor radon levels arising from groundwater. This may be due to the wide distribution of its daughter products in the environment, soils and the natural water (Garba et al., 2008; Mustapha et al., 2002). The high

${ }^{222} \mathrm{Rn}$ concentration may be as a result of ${ }^{222} \mathrm{Rn}$ release from the surrounding geological formation. Concern for exposure to radiation from ${ }^{222} \mathrm{Rn}$ sources has necessitated studies to reduce/mitigate the dangers.

The annual effective dose due to ingestion of 222Rn in the water varied from 0.010 to 0.0989 $\mathrm{mSv} / \mathrm{y}$, with an average of $0.0412 \mathrm{mSv} / \mathrm{y}$ for both underground and surface water. International organizations have established recommended limits for ${ }^{222} \mathrm{Rn}$ concentration in water but Nigeria has not introduced any legal regulation concerning permissible radon concentration in water yet; therefore, there is need for radon concentration in water to be investigated thoroughly so that guidelines for regulations on the radon concentrations in Nigeria may be established.

\section{Conclusion}

The present study showed that the radon concentration in the ground water and surface water samples from Idah and its environs has been found to have an average mean ${ }^{222} \mathrm{Rn}$ concentration of $12.28 \mathrm{~Bq} / \mathrm{L}$ for boreholes, $10.23 \mathrm{~Bq} / \mathrm{L}$ for well water and $3.05 \mathrm{~Bq} / \mathrm{L}$ for surface water. Both borehole and well recorded radon concentrations above the maximum limit of $11.1 \mathrm{~Bq} / \mathrm{L}$ set by USEPA (1991) and 10.0Bq/L by WHO (1993) and UNSCEAR (1993) which call for immediate action for radon reduction. Also comparing the result with the value $0.1 \mathrm{~Bq} / \mathrm{L}$ set by the Standard 
Organization of Nigeria SON (2003), it was observed that all the water samples assayed for radon concentration are not safe for domestic purposes and consumption. It is expected that the people of Idah and its environs may likely suffer from stomach cancer, lung cancer, leukemia, chronic diseases etc. because of the high ${ }^{222} \mathrm{Rn}$ concentration in ground water and surface water from these sampled location as they are taking the water directly without no or proper treatment for radon in water. The dose annual effective dose ingestion was found to be in the range of $0.0010 \mathrm{mSv} / \mathrm{y}-0.0989 \mathrm{mSv} / \mathrm{y}$ with an average annual effective dose by ingestion found to be $0.0412 \mathrm{mSv} / \mathrm{y}$ which is lower than the recommended limit for members of the public of $1.0 \mathrm{mSv} / \mathrm{y}$ and an intervention level of $3-10 \mathrm{mSv} / \mathrm{y}$ set by the International Commission on Radiological Protection (ICRP, 2005). The results showed the samples from underground water (boreholes and well) are not safe for human consumption but samples from surface water have less radon concentration due to its exposure to the atmosphere and is recommended for domestic use. Hence, the data obtained in this study could be used for the study location, since this work pioneer the determination of radon in ground and surface water in the study location.

\section{References}

[1] American Society for Testing and Materials, ASTM. (1999). Standard test method for Radon in drinking water. ASTM Designation: D5072-98.

[2] Cho J. S., Ahn J. K., Kim H. C., Lee D. W. (2004). Radon concentration in groundwater in Busan measured with a liquid scintillation counter method. Elsevier Env. Rad. 75:105-112.

[3] Cothern C. R. (1990). Estimating the health risks of radon in drinking water. J. American water works assoc. no. 157.

[4] Darko, E. O., Adukpo, O. K. \& Fletcher, J. J. (2010). Preliminary studies on 222Rn concentration in groundwater from selected areas of the Accra metropolis in Ghana. J. Rad. Anal. Nucl. Chem., 283, 507-512.

[5] Farai, I. P. \& Sanni, A. O. (1992). Yearly variability of 222Rn in a groundwater system in Nigeria. J. Afr. Earth Sci., 15(314), 399-403.

[6] Galan Lopez, M., Martin Sanchez, A., Gomez Escobar, V. (2004). Application of ultralow level liquid scintillation to the determination of $222 \mathrm{Rn}$ in groundwater. J. Rad. Anal. Nucl. Chem., 261(3), 631-636.

[7] Garba, N. N., Rabi'u, N., Yusuf, A. M. \& Isma'ila A. (2008). Radon: Its consequences and measurement in our living environs. J. Res. Phy. Sci., 4(4), 23-25. Preliminary Studies on 222Rn Concentration 64.

[8] Garba, N. N., Rabi'u, N., Isma'ila, A., Yusuf, A. M., Abubakar, A. K. \& Yamusa, Y. A. (2010). How safe is a radiation dose. Int. J. Phy. Sci., 3(2) 9-14.

[9] IAEA. (2001). Water for people, water for life. The United Nation World Water Development Report. http:/www.unesdoc.unesco.org/images/ 0012/001295/129556e.pdf.

[10] ICRP, (2005).International Commission on Radiation Protection, Annals of ICRP 60: $411-440$.

[11] Mustapha, A. O., Patel, J. P. \& Rathore, I. V. S. (2002). Preliminary report on Radon concentration in drinking water and indoor air in Kenya. Environ. Geochem. Health, 24, 387-396. 
[12] Paul, B. H. and Stephen, H. P. (1991). Determination of Radon in Drinking Water by Liquid Scintillation Counting Method 913.0. U. S. Environmental Protection Agency, Las Vegas, Nevada.

[13] Slevasekarapandian, A., Tripathi, R. M., and Puranik, V. D. (2001). Occurences of NORMS and 137Cs in Soils of Singhbhun Region of Eastern India and Associated Radiation Hazard. Radiation Protection. 44(1): 56 - 68.

[14] Standard Organization of Nigeria (SON) (2003). Inorganic Constituents for Drinking Water Quality.

[15] Thomas, M. A. (1987). A Connecticut radon study-using limited water sampling and a statewide ground-based gamma survey to help guide an indoor air testing program. In Barbara, G. (Ed.). Proceeding of a conference, report on Radon, Radium and other Radioactivity in Airborne contamination. National Water Works Association, Lewis Publishers, 347-362.

[16] United Nations Scientific Committee on the Effects of Atomic Radiation, UNSCEAR. (1993). Sources and effects of ionizing radiation, UNSCEAR report to the general assembly with scientific annexes, United Nations, New York.

[17] United State Environmental Protection Agency, USEPA. (1991). National primary drinking water regulations for radionuclides. Washington: U.S. Government Printing Office.

[18] USEPA. (1999). Health risk reduction and cost analysis for radon in drinking water. Federal register 64(38), 9559, Washington.

[19] USEPA. (1992). Technical support document for the 1992 citizen's guide to radon. EPA 400-R-92-011.

[20] Williams, G. C. (1977). Sampling Techniques. 3rd Edition. Wiley, New York, PP 89 92.

[21] World Health Organization, WHO. (1993). Guidelines for drinking water quality, vol.1, 2nd ed. Geneva: WHO.

*Corresponding author.

E-mail address: aroaruwa @gmail.com 